\title{
4. Embodied teaching and learning through a large lecture: strategies for place-based pedagogies
}

\section{Matt Finn and Carrie Mott}

\section{INTRODUCTION}

This chapter is the result of several months of dialogue between the authors regarding the challenges of geography lectures of 200 or more undergraduate students and the practical strategies we employ in our respective classrooms. Throughout, we discuss our personal positionalities and contexts, and how our decisions and strategies for teaching large lectures have emerged. In addition to our differently gendered identities, we also write from two distinct national contexts (the United Kingdom and the United States), something which we discovered has a powerful impact on the ways we approach teaching. Our dialogue was informed not only by our differences, but also through a similar background in education with children. Matt taught in a secondary school in the UK prior to pursuing his studies in Geography, and Carrie worked in elementary education in both public and Montessori charter contexts in the US before completing a $\mathrm{PhD}$ in Geography. We both feel that our teaching backgrounds outside of higher education have provided us with pedagogical skills that have been assets to the large lecture classroom. Further, we have found that teaching young adults is not necessarily so different from teaching children and embrace 'the idea that learning at university can be fun and creative' (Bovil, 2018, p. 2). It is not without challenges, however, and, as Jenkins et al. (1993) note, runs alongside the question how to teach a large lecture in geography, specifically, and to develop strategies that speak to core disciplinary concepts (see also Tasch and Tasch (2016) on the implications of large lectures for teaching physical geography).

We have constructed this chapter by reflecting on dialogue that occurred through video chats and email exchanges and illuminate some of the successes, frustrations, and practical strategies that have been a part of large lecture teaching for both of us. Further, our conversation offers insights into the often significant differences in how we teach that are related to our respective contexts and positionalities, including gender, but also job security, levels of institutional support, and national political climate. For example, Matt has experienced much higher levels of institutional support for teaching, as well as more oversight where subject matter and class organization are concerned. In contrast, Carrie has experienced significantly less institutional support for teaching, but enjoys a high degree of creative freedom in course design. Our relative institutional contexts certainly contribute to different experiences. In Carrie's case, most students enrolled in order to fulfill a university general education requirement, and were not geography majors. However, students in Matt's classes are typically pursuing a degree in 
geography, and so his students are more likely to view the classes as connected to their longer-term ambitions.

The dialogue that follows is organized around three core themes, each a common thread which appeared consistently throughout the conversations. The first, 'The Emotional and Embodied Experience of Teaching a Large Lecture' provides an introduction in which we talk through the challenges, frustrations, and successes of the large lecture, and how the educator's experience carries over into one's ability to educate effectively. The second, 'The Role of Context in Teaching a Large Lecture' includes our reflections on aspects of our teaching that we found to be similar or different due to our respective positionalities and overall contexts. Through the third and final theme, 'Strategies for Enhancing Teaching a Large Lecture', we discuss the practicalities of student engagement in large lectures and specific ways we each work to provide students with an individual learning experience, despite the anonymity that is created by large numbers in the room.

\section{THE EMOTIONAL AND EMBODIED EXPERIENCE OF TEACHING A LARGE LECTURE}

The question of emotion and embodiment is an important one, because it speaks directly to the mental and physical well-being of the teacher in the performance of a large lecture. This can be a challenge, especially for early-career academics and graduate students, who may find themselves teaching for the first time without much preparation, unless they have sought it out themselves (Grasgreen, 2010). This section also offers some reflection into how the classroom can be a space of either 'possibilities or despair for students and teachers, and our aims to maintain sensitivity to students' experience' (RezaLopéz et al., 2014, p. 109). However, we also see the classroom as a critical site for 'political consciousness raising' (Inwood, 2017, p. 454), and understand that discomfort can be an important pedagogical tool when we strategically mobilize 'controversy capital' in the classroom - the amount of emotionally charged or controversial subject matter that an educator can realistically handle (LaLiberté et al., 2017, also Dowler, 2002; see also Chapter 18 in this volume on teaching challenging material by Maddrell and Wigley). Here we talk through how we manage our own emotion and energy in teaching a large lecture, as well as our approach to politically sensitive topics, and offer some advice for how one should prepare oneself to teach a big lecture, particularly for those who may have very little experience teaching.

CM: How do you balance the challenge of the energy required to teach big classes? On days when I teach more than one class, I find that I can be really wiped out by the end of the day. 
MF: I did a lecture on day two of the term and felt like it must be nearly the end of term given how tired I felt! Considering what one needs afterwards (quiet, food, and rehydration for example) and making sure that, where you can, you give yourself time to recover is important.

CM: After my first lecture in my 260 student class, I couldn't believe how drained I was. In part this had to do with the hectic pace of the beginning of a term. But it was also from having to fill this enormous room with my voice. There is a real physiological thing that happens when you lecture like that.

MF: It's a kind of self-projection, through your voice and persona, in occupying the space which can be very draining. If the term/semester is a marathon of sprints it's about working out how to pace yourself within that. There is an emotional labour to working in education, and I find this is often heightened when dealing with difficult topics. We may discuss a range of contentious issues in lectures. It is important, I think, that they know they can disagree, although a lecture may not be the best venue to voice or explore that disagreement. Offering 'balanced' views or attempting neutrality can be important for some issues whilst in others the lecturer can make it clear that they are making an argument (and modelling a way of doing this) and so are going to be partisan. Either way, this can be emotionally charged work. How does this work out for you?

CM: I don't want to avoid challenging topics in a large class, but it does require caution. I try to control the conversation when sensitive topics come up, often in a large class I deliberately do not ask for questions or comments, I will just speak on the topic and move on. In the bigger lectures, it is difficult to gauge where your students are at. I definitely agree with the strategy of presenting different sides of the issue to portray it in as neutral a way as I can. People are more receptive to difficult topics when they don't feel attacked, or as if they are to blame.

MF: I've noticed that some students distance themselves from some of the topics that are controversial as being 'out there', so trying to create a space to supportively work through and engage personally challenging issues is important here, but can be very hard to achieve.

CM: After the November 2016 US presidential election I was very nervous to talk about any of the things that were happening because I didn't trust my own emotions about it all - I knew I could not act as if I was neutral on the topic. It was just too volatile. In general, I do work to incorporate recent current events. My approach is rooted in case studies which I use to illustrate the theoretical themes I'm working with. I've been thinking more about how to talk about things like nationalism and the nation, place, inequality, and so on in relation to the Trump administration. I will still move cautiously, but I don't want to ignore or talk around it either. 
MF: I agree, as hard as it can be engaging with our contemporary moment, it seems crucial for those of us who consider ourselves as educators and not just 'instructors'. To facilitate or lead discussion can pose risks for us and some, or all, of our students, and so there is a need for wisdom, courage, and humility. I think we should also recognize how little we know about our students and their lives, and be cautious about imputing motives to what we see of their behaviours in class. I do think we need courage to persist, in community and with support, in the process of education that can be as demoralizing as it is rewarding. Without training, practice and encouragement it can be very challenging to project confidence or 'hold a room' with a sense of authority. What advice would you give colleagues who ask you about this?

CM: There can be a steep learning curve and it is often very challenging for someone who does not have much experience or training as a teacher. Particularly for those of us who come from institutions and departments that emphasize research over teaching - someone may do amazing grant-funded research, but that doesn't mean we know how to teach. You have to perform as if you embody those things and project yourself accordingly. Something you said, Matt, in one of our conversations was that teaching the big lecture is actually a lot like performing stand-up comedy and I think this is so true!

MF: To be clear: I don't think of myself as a comedian! Certainly, students don't laugh at my attempts at jokes (they humour me perhaps!), but I do think that there are not many other forms of public speaking where people sit and listen, in person, for extended periods. The two other places I can think of are speeches made at political rallies and religious sermons. I have done a bit of preaching in a church and was given some training on this, which was useful on how one clarifies key messages, thinks about audiences, and develops an authentic and effective presenting style. Although it's not something I typically talk about I think this has informed my experience too. There may be things to learn from streaming services too concerning maintaining attention or in how media engagement has become more social. For example, some lecturers use Twitter and messaging services to enable dialogue and questions during lectures.

CM: There is a lot of power in the 'fake it 'til you make it' strategy - I have used this myself many times. This means that even if you don't feel knowledgeable, students don't know this.

MF: Yes, and even with some training, lecture hall experience can be a good, if cruel, teacher! One frustration is that some lecturers I've observed start with an apology for the session for one reason or another. I want to say to them: don't undercut yourself at the beginning - you are effectively saying, 'I give you permission not to listen or engage with this, I don't have confidence in the material or myself'. The students are looking to the lecturer to set a tone or atmosphere even though it is, in the end, co- 
produced. They expect you to set them at ease and to foster a sense of a positive and safe space for learning.

CM: Ultimately, it's one of those things that you have to dive into and learn through doing. We are both people with professional backgrounds in education and well as other public speaking experience - but knowing how to lecture effectively to 200+ people (and guard your own emotions and energy at the same time) is something you have to develop through experience.

\section{THE ROLE OF CONTEXT IN TEACHING A LARGE LECTURE}

In this section we reflect on the ways in which the lecture space is embedded in, and not sealed off from, the wider society and local milieu in which we educate. Paying attention to these contexts informs our work as educators in general but also some of the approaches we may take to large lecture teaching in particular. Students educate us about the way they see the world, the university, and themselves, in a range of verbal and non-verbal ways as we lecture, as well as through interactions in hallways, meetings and assessments. In this way, the large lecture is emphatically not as some would have it a monologue or 'one-way technology' (Twigg, 1994, p. 14 in Jones, 2007, p. 200). Context varies across a range of aspects of the educational experience from the institutional setting to the composition of the student body and the identity of the educator. All of these are refracted through experiences of the increasingly neoliberalized academy (SIGJ2 Writing Collective, 2012) - or at least its financialization (Barnett, 2018). Many academics, and indeed students, face a precarious and indebted present and uncertain futures and this too shapes the conditions of possibility for education.

MF: In our conversations we've talked about how we are not only learners of what we teach but also of our students, our campuses, our wider geographies, and our times (Freire, 1970; Mrs Kinpaisby, 2008; Giroux, 2010). We noticed that we bring something of our sensibility and training as geographers to making sense of the different spaces of education we inhabit. How do you pay attention to context as a geography educator?

CM: Context is very important. At Rutgers ${ }^{1}$ I've been able to teach much differently than I could at my previous university. In part, this has to do with where students are when they come in (skills and readiness of the average freshmen), but it also has a lot to do with a much more diverse student body. When I teach about racialized injustice, for example, many of my Rutgers students are already familiar with these ideas. They may not have the same language or theoretical framing that I offer them, but they are not new to the concept, which is a much different experience than working with people who are unfamiliar with concepts such as social privilege, or systemic injustice. 
MF: As a contrast then, the two contexts I am most familiar with have been white-majority universities where a greater than average percentage of students come from socio-economically advantaged backgrounds. I am conscious of how issues of inequality and injustice can be understood as learning about 'others', 'out there' and how this can affect the students in the class for whom the topics being talked about resonate much more with their own experiences.

CM: Whatever the diversity of the student body, I try never to assume that my students already know these things - rather, I use a lot of scaffolding when I teach (Vygotsky, 1962; Roberts, 2011). This means that I offer different levels of information, ranging from very basic to more theoretical and complex. In this way I feel like I've been able to serve the diverse student body which I work with here. I'm always aiming to engage and challenge people from different backgrounds simultaneously, including those who hold different political ideologies. I think my own identity is helpful in this regard, I'm from a socially and politically conservative area that is predominantly white - so I am very familiar with those points of view. I'm typically teaching against hegemonic social norms that support those views, in keeping with bell hooks' (1994) concept of 'teaching to transgress', but I try to do so with patience and empathy for students who hold more conservative views. How do you think your identity shapes your approach to teaching large classes?

MF: I think I come across as warm and joyful but also sometimes as quite intense and having high expectations. Part of my role involves handling cases of suspected plagiarism and so being known for this means that some students say they think I'm scary, but students also say I'm a very approachable member of staff. I am a younger academic, and in a teaching-focused post (though I don't know how many students know this or differentiate between staff on different types of contract). With my prior education experience I think I'm am quite 'teacherly' in terms of owning the room (a colleague said I was very 'authoritative', which I didn't quite know how to take, but said I had presence and was persuasive) but also perhaps willing to be a little bit more 'goofy' when the occasion calls for it than some lecturers who have a more consistently earnest demeanor. How about you?

CM: I think I come across as kind and nurturing, the typical feminine stereotypes. But I don't mind it really. I want my students to feel safe with me, and to feel that I care about them. I do think this comes back to bite me a bit at times though, for example at the end of a semester, when people are scrambling for grades, trying to convince me to give them a higher grade than they earned, etc. I tend to be very strict about that sort of thing unless it's someone I've been working with all semester long. When someone comes out of nowhere at the end of the semester, I don't tend to bend where grades are concerned. I think this is probably an unpleasant surprise for students who think 'she's nice' and that I will accommodate whatever it is that they want me to do. I've found that I have to be very firm about boundaries around this sort of thing with certain students and use rather strong language, especially 
since it is known that students often expect a lot more out of female faculty in terms of granting exceptions and that sort of thing (Flaherty, 2018).

MF: I'm aware that some students are much more 'pushy' with younger female colleagues than I think they would be with me. Some students effectively ask for some of their work to be done for them - 'can you give me a reading list', 'what should my approach/structure be for this essay'? I do get asked this but it seems to be accepted when I turn things back to them - what do you think? Where could you go to find out? When one female colleague did this she endured some verbal harassment. Beyond gender, the difference in female staff evaluations and for academics of colour are well documented (Kishimoto and Mwangi, 2009; Gutiérrez y Muhs et al., 2012; Hsing-Chen, 2012; Mengel et al., 2018). Does this resonate with your experience?

CM: Gender absolutely factors into how I am perceived, in the classroom as well as with colleagues. In the classroom, I feel like the perception of my gender is both something beneficial as well as a challenge. I see that I am a role model for young women and I take this very seriously. I know that students see me as someone who genuinely cares about them and wants to help them be successful. However, I do often wonder if the young men in the class would be so comfortable talking in the back of the room if I were male. I also know that there is a culture of competitive aggression that is used to signify intelligence. I don't buy into this at all personally, and work to resist it in my day-to-day life, but I also observe how that dynamic of competition and aggression is often perceived as intelligence when it comes from men.

\section{STRATEGIES FOR ENHANCING LARGE LECTURE TEACHING}

In this section we consider practical strategies, borne out of experience, and explored in literature on large lecture teaching. Where pedagogic literature suggests effective strategies, the large lecture poses particular challenges so that these cannot be merely 'applied' but have to be worked through in relation to the context of the education space, as we have discussed above. The large lecture can be understood as a 'contact zone' (Askins and Pain, 2011) in which people, objects and ideas can be brought into uneasy but transformative interaction. However, this potential for transformative interaction is not automatic (as Askins and Pain (2011) discuss) but flourishes under particular conditions of possibility and engagement. Naturally, we strive to make our lectures 'unmissable' (Revell and Wainwright, 2009) and emphasize that engaged attendance correlates with stronger grades (Clark et al., 2011), but the scale and anonymity of a large lecture can make this difficult. We explore this further in our discussion below on the practical strategies we have adopted in our large lecture teaching. 
MF: In our conversations we have discussed the repertoire of practices that we draw on in large classes and how we use our sense of our context to tailor strategies from this repertoire to the places, people and times in which we teach. Before we get into that could you say a bit about how your repertoire draws on experiences of teaching outside of Higher Education?

CM: Really, in many ways - teaching at university level is not that different from working with children! You have to think about a lot of the same kinds of things - scaffolding your lectures and assignments, for example. This means that you are always building different levels of understanding into everything you do so that it will be interesting and engaging for students who bring different skills to the table. Scaffolding also means that you aren't penalizing those students who may be inexperienced with the topic in an introductory class, but you are still keeping it interesting for those who are already familiar with the material (Cantiello, 2013).

MF: I think there's a lot that I learnt there about communication, breaking tasks down, thinking about the progression of tasks or a set of material and also 'classroom management', as you put it. In a recent geographies of education lecture I discussed how this is a technique of 'schooling' through trying to maintain a student's attention (Gallagher, 2004). I think of myself as designing moments for learning and resources for teaching that try to work at the level of 'experiences'.

CM: I have seen where my previous experiences working with children have given me a heightened awareness to some of these fundamentals of teaching/learning. For example, how to very clearly write out assignment expectations and formulate concrete steps for students to take. Or, how to map out the arc of a semester in terms of the types of assignments I will offer and things we will do in relation to my own time and capacity for grading and staying on top of my responsibilities along the way. One assignment I give in my introductory lecture course asks students to respond in a short essay to a section in their textbook on, for example, Fordism and Post-Fordism, showing that they are engaging with core concepts in economic geography, and relate it back to material presented in lecture. They are required to address a set of questions through their response and focus on particular parts of the chapter. Ultimately though, I am not looking for a standard answer, I just want to see engagement with these basic economic geography concepts at whatever level works for the student. For some who are new to the subject, their responses may be very basic while still fulfilling the parameters of the assignment, whereas others will have advanced knowledge of the material and provide a much more developed essay.

MF: The strategies we use can complement these other ways in which we think about progression, the goals of learning and assessment. What would be an example then of something you do in the lecture? 
CM: I do a lot of 'in-class exercises', which are typically 5-10 minutes in the middle or near the end of class where I ask students to take out a piece of paper and engage with a prompt of some kind, or talk with their neighbor in response to a few questions (Gonzales, 2015). These are not graded for content - it is a quick attendance check and, at the end of the semester, gives me some idea of the percentage of classes a student attended overall. I try to keep these in-class exercises creative and fun; usually I am asking them to think of something that relates to the topic at hand. I find that it is much easier to get people to engage after I have given some time for them to gather their thoughts on a topic. For example, I have a section of my intro to human geography class that looks at the concepts of utopia and dystopia, and how those ideas were mobilized through European colonialism. The prompt I will throw out to students is, 'What is one example you can think of from a film, television show, or book that shows a dystopian view of the future?' Then I give 3-5 minutes for them to jot down some ideas. This one is fun, because people think of very interesting examples (often things I am not familiar with!), and I will have students explain the basic plot to the rest of the class. It's a light-hearted way to get into the topic and have them think about ideas that we are dealing with in class which show up a lot in popular culture.

MF: I do the same thing with in-class exercises. I might ask them to respond or join in with some conversations and then I report back to the group. I've also sometimes set prompts which I ask students to respond to outside of class. I bring what they say (anonymized) into class time and use them to stage a dialogue. I've also tried live web-based comment boards like padlet ${ }^{2}$ (Padlet, 2018) and electronic quiz options but I think you have to be quite confident about using these to give it a go and they operate on a spectrum of more to less structured. It is important to mediate the risk of students using this inappropriately. With padlet I would set out my expectations at the beginning of a session about what I think professional conduct would be and make it clear that I will not use this platform if I am concerned it is being used inappropriately. Some approaches like structured roleplays, the goldfish bowl ${ }^{3}$ (GP training net, 2018), or 'staged seminar approach' can be effective, which draw on different forms of staging or drama-work.

CM: Another strategy is to wander the room while students are working through the exercise and talk to some people individually - this way you can also hear from people who don't normally speak in class and tell them that you'd like to call on them when you bring the large group together so that they are prepared. The anxiety factor for students is certainly a concern - but this also has to be mediated with the fact that speaking in front of a large group is a skill that they will be developing throughout their university education, it is beneficial to have a little experience with it.

MF: I have also been thinking about what it looks like to do a lecture well, rather than trying to make it something it can't be. A common pitfall that I've observed is trying to run multiple smaller seminars or workshops within the lecture hall - the lecturer wants the experience to be dialogue-based but is 
fighting the size of the lecture. There are productive versions of this (for example as above) but to 'monologue' well is a skill in itself and something which can be honed as an effective pedagogy. I'm also not persuaded that a monologue is ever a voice on its own in any case; what we say is shaped and formed in conversation with literature, our context and at its best, with our students. Do you find you tend to adopt a more monologic approach in a large lecture?

CM: While I work hard to shift the dynamics of power and authority around in small classes, with my current class of 260 this would be significantly more challenging. I do think that the tradition of 'lecture as monologue' is rooted in patriarchal and authoritarian norms (Friere, 1970; Dowler, 2002) which discipline students to assume that they have little to offer coming into a class and should be there to listen and learn from an implicitly male teacher. However, it is really difficult to overturn the normative expectation of a monologue because most students have been successfully disciplined to embody a passive role in lecture. I suppose this is one of the more difficult things about the large lecture - trying to upset this dynamic and the way that students and educators have been trained to behave. The physical layout of a lecture hall presents additional challenges to a dialogic approach - seats are fixed in place; inability to move freely around a tightly packed, terraced room; and so on. As a geographer I am constantly thinking about these spatial challenges to teaching, which stem from how the classroom itself was designed and engineered.

MF: Yes! The room makes a real difference and we can read the philosophies of knowledge built into the design. However, the paper by Hill et al. (2016) challenges a risk of determinism in arguing that the space does not have to define the type of teaching that is possible. They argue that while there are dominant assumptions about learning embedded in the architecture of spaces, it is possible to use these affordances creatively. I try to make something of this in one of my lectures in quite a simple way. I start the lecture sitting down in the middle of where the students sit and narrate from there something about how to read this space and how it might be hard - but that it is possible - to overcome some of the disciplining you talk about. I remember too, that you talked about how to make space for students to get to know each other in lectures. Could you say a bit about that?

CM: Yes, this is a really important aspect of teaching the large lecture that is often overlooked. For the most part, unless you are at a fairly small school, your students don't know each other when they begin the class. Especially if you are going to attempt to do in-class exercises where they are paired or grouped together, you have to give them opportunities to get to know each other. In my course evaluations for my big lecture, I have had multiple students write that they appreciate that they were able to get to know other students in the room, because this often doesn't happen in big classes. There are simple ways to do this - on the first day of class, for example, I asked them to take a piece of paper and a pen and to find out from three of the people sitting near them their name, major (or intended major), and hometown. 


\section{CONCLUSIONS}

In this dialogue we have drawn attention to three key themes from conversations had over several months. Namely: the emotional and embodied experiences of teaching a large lecture; the role of context; and strategies for enhancing teaching a large lecture (see Chapter 5 in this volume by Rink for strategies for assessment of large cohorts). Teaching in these contexts necessitates a particular performance of the self in space: of skills; experience; and flexibility according to the needs of our students. We have considered this as a form of place-based pedagogy where responding to the conditions of the room, our institutional and national milieu, our students, and their lifeworlds, means we cannot simply apply 'good practice' or 'what works' aspatially and impersonally, but with attentiveness to our contexts. We advocate here for a recognition of the challenges and successes brought to the embodied and placed performances of teaching that values the creativity required to meaningfully co-produce knowledge with our students.

In particular, we highlight themes from this chapter and next steps which follow from recognizing the labour of this work and some potential implications for those taking large lectures (Table 4.1).

Table 4.1 Forms of academic labour and their implications

\begin{tabular}{|c|c|}
\hline Forms of academic labour & Implications \\
\hline $\begin{array}{l}\text { A recognition that large lecture teaching is } \\
\text { physically tiring and emotionally draining (just } \\
\text { as it can also be fun and exhilarating). It requires } \\
\text { a set of bodily and cognitive performances to } \\
\text { project your voice, to create ties of engagement } \\
\text { with students across the large spaces, to hold } \\
\text { attention and communicate meaningfully, such } \\
\text { that the large lecture becomes a space for } \\
\text { learning. }\end{array}$ & $\begin{array}{l}\text { Consider how you build up to, and rest from, } \\
\text { delivering large lectures and what you schedule } \\
\text { before, and following, them. What aspects of } \\
\text { self-care could you engage in to protect your } \\
\text { voice and physical and emotional wellbeing? } \\
\text { What support or training could you access from } \\
\text { your institution or union? Consider if there are } \\
\text { trusted colleagues you could ask to give you } \\
\text { peer feedback on this aspect of your lecturing, } \\
\text { and discuss with other colleagues their strategies } \\
\text { as a form of peer learning. }\end{array}$ \\
\hline $\begin{array}{l}\text { A recognition that sitting in large lectures is } \\
\text { often tiring for students, who are asked to }\end{array}$ & $\begin{array}{l}\text { Consider how you could change the dynamic of } \\
\text { the space to allow for different modes of }\end{array}$ \\
\hline
\end{tabular}




\begin{tabular}{|c|c|}
\hline $\begin{array}{l}\text { concentrate for extended periods of time to } \\
\text { engage with difficult and often new ideas, in } \\
\text { environments that may be unfamiliar and } \\
\text { alienate and in which other students may act as } \\
\text { learning partners and distractions. }\end{array}$ & $\begin{array}{l}\text { interaction and encounter. Consider how you } \\
\text { could change the dynamic of the experience of } \\
\text { time (and pacing) of the large lecture to work } \\
\text { with concentration spans and re-engage attention } \\
\text { at different points. }\end{array}$ \\
\hline $\begin{array}{l}\text { A recognition that controversy has a place in the } \\
\text { large lecture but that 'doing controversy well' } \\
\text { places additional burdens on the lecturer and the } \\
\text { students as well as being empowering of voices } \\
\text { and positions that may otherwise not have felt } \\
\text { heard in other spaces on campus. }\end{array}$ & $\begin{array}{l}\text { Consider what some of the areas of controversy } \\
\text { are in your subject area. This may vary and be } \\
\text { more or less emotionally affecting for students. } \\
\text { Consider your own sense of confidence about } \\
\text { hosting conversations like these. How does that } \\
\text { affect what you might or might not do? }\end{array}$ \\
\hline $\begin{array}{l}\text { A recognition that our students are diverse and } \\
\text { lead lives which are at least as complex, and } \\
\text { sometimes more so, than their lecturers. Their } \\
\text { learning and experience of university extends far } \\
\text { beyond that which we may be able to 'read' } \\
\text { from demeanour and conduct in large lectures. }\end{array}$ & $\begin{array}{l}\text { What assumptions might you be making about } \\
\text { your students based on what you see in the large } \\
\text { lectures? How can you engage students outside } \\
\text { of classes to break down these assumptions? } \\
\text { One practice is to convene a voluntary student } \\
\text { focus group which meets periodically through } \\
\text { the course to provide feedback and ask questions } \\
\text { which then inform your teaching. }\end{array}$ \\
\hline $\begin{array}{l}\text { A recognition that the wider context of higher } \\
\text { education and geographical variability and } \\
\text { differing inequalities shape the conditions of } \\
\text { possibility for large lecture teaching. Good } \\
\text { practice cannot simply be 'applied' but the } \\
\text { educator implements approaches, techniques, or } \\
\text { strategies in embodied and spatially-specific } \\
\text { ways. }\end{array}$ & $\begin{array}{l}\text { What are the challenges and opportunities your } \\
\text { students face in the context of your institution } \\
\text { and regional and national setting. Are they (and } \\
\text { colleagues) facing financial hardship, } \\
\text { discrimination, or mental health difficulties? } \\
\text { Discuss with colleagues how they consider and } \\
\text { respond to these issues. }\end{array}$ \\
\hline $\begin{array}{l}\text { A recognition that typical lecture spaces, and the } \\
\text { form of a lecture, bears the inheritances of } \\
\text { particular politics of knowledge that enhance the } \\
\text { cultural status of the lecturer through the } \\
\text { invalidation of the knowledge of students. A } \\
\text { variety of alternative approaches allow for the }\end{array}$ & $\begin{array}{l}\text { What do you consider your role to be as a } \\
\text { lecturer? If knowledge is more distributed and } \\
\text { not invested solely in the academic how does } \\
\text { this affect your teaching practice? Which } \\
\text { approaches do you use already, and which } \\
\text { would you consider trying? What conditions }\end{array}$ \\
\hline
\end{tabular}


large lecture space to be one of shared meaningmaking, which values the distinctive contributions of participants. would enable you to consider other strategies or approaches? What one 'small change' (Lang, 2016) could you incorporate in your next large lecture?

One need not be uncritically committed to the merits of large lectures to recognize their continued value and contribution to learning in a higher education setting, despite relevant critiques of neoliberalization of the academy. Indeed, as we think this dialogue makes clear, it is precisely by engaging with the challenges of the lecture, by attending to the contexts in which we work, and by opening up dialogue with our students that we can ensure some of the possibilities of the large lecture are realized.

\section{USEFUL RESOURCES}

- Anmpalagan, R. and Smith, R. (2018) Large Class Teaching Challenges and Possible Responses. Available at https://warwick.ac.uk/fac/soc/al/research/groups/llta/resources/telc/strategies/ (Accessed: 26 April 2019).

- Lang, J.M. (2016) Small Changes in Teaching. Available at: https://www.chronicle.com/specialreport/Small-Changes-in-Teaching/44 (Accessed: 23 February 2018).

- Wilsman, A. (2016) Teaching Large Classes. Available at https://cft.vanderbilt.edu/guidessub-pages/teaching-large-classes/_(Accessed: 26 April 2019). </list>

\section{NOTES}

\footnotetext{
${ }^{1}$ Carrie was an Instructor with the Department of Geography at Rutgers, The State University of New Jersey from 2016 to 2018.

2 https://padlet.com/

${ }^{3}$ http://www.gp-training.net/training/vts/group/goldfish.htm
}

\section{REFERENCES}

Askins, K. and R. Pain (2011) 'Contact zones: Participation, materiality, and the messiness of interaction', Environment and Planning D, 29(5), pp. 803-821.

Barnett, C. (2018) The Means and Ends of Higher Education. Available at: 
http://www.journalofculturaleconomy.org/the-means-and-ends-of-higher-education/ (Accessed: 28 March 2018).

Bovil, C. (2018) 'Lectures and Legoland: Recapturing the excitement of learning', Dansk Universitetspaedagogisk Tidsskrift, 13(24), pp. 1-4.

Cantiello, J. (2013) Fourth Grade Lessons. Available at:

https://www.insidehighered.com/advice/2013/08/16/essay-job-search-move-elementary-schoolcollege (Accessed: 23 February 2018).

Clark, G., Gill, N., Walker, M. and R. Whittle (2011) 'Attendance and performance: Correlations and motives in lecture-based modules', Journal of Geography in Higher Education, 35(2), pp. 199-215.

Dowler, L. (2002), 'The uncomfortable classroom: Incorporating feminist pedagogy and political practice into world regional geography', Journal of Geography, 101(2), pp. 68-72.

Flaherty, C. (2018) Dancing Backwards in High Heels. Available at: https://www.insidehighered.com/news/2018/01/10/study-finds-female-professors-experience-morework-demands-and-special-favor (Accessed: 23 February 2018).

Freire, P. (1970), Pedagogy of the Oppressed, New York: Continuum.

Gallagher, M. (2004) Producing the Schooled Subject: Techniques of Power in a Primary School, $\mathrm{PhD}$ thesis, The University of Edinburgh.

Giroux, H. (2010) Lessons to be Learned from Paulo Freire as Education is Being Taken Over by the Mega Rich. Available at: http://www.truth-out.org/archive/component/k2/item/93016:lessons-to-belearned-from-paulo-freire-as-education-is-being-taken-over-by-the-mega-rich (Accessed: 23 February 2018).

Gonzales, J. (2015) The Big List of Class Discussion Strategies. Available at: https://www.cultofpedagogy.com/speaking-listening-techniques/ (Accessed: 23 February 2018).

GP training net (2018) Goldfish Bowl Technique. Available at: http://www.gptraining.net/training/vts/group/goldfish.htm (Accessed: 23 February 2018).

Grasgreen, A. (2010) Preparing Professors to Teach. Available at: https://www.insidehighered.com/news/2010/10/15/mit (Accessed: 23 February 2018).

Gutiérrez y Muhs, G., Flores Niemann, Y., González, C.G. and A.P. Harris (2012) Presumed Incompetent. Logan: Utah State University Press, Project MUSE.

Hill, J., Thomas, G., Diaz, A. and D. Simm (2016) 'Borderland spaces for learning partnership: Opportunities, benefits and challenges', Journal of Geography in Higher Education, 40(3), pp. 375393. 
hooks, b. (1994) Teaching to Transgress. New York: Routledge.

Hsing-Chen, Y. (2012) 'Feminist teaching practice in masculine higher education institutions in Taiwan', Asian Journal of Women's Studies, 18(3), pp. 7-37.

Inwood, J. (2017) 'Critical pedagogy and the fierce urgency of now: Opening up space for critical reflections on the U.S. civil rights movement', Social and Cultural Geography, 18(4), pp. 451-465.

Jenkins, A, Daniel, P., Healy, M., Hindle, B., Keene, P., Mills, C., McEwen, L., Robinson, G., Rodaway, P., Slowe, P. and D. Rolls (1993) 'Teaching large classes in geography: Some practical suggestions', Journal of Geography in Higher Education, 17(2), pp. 149-162.

Jones, S.E. (2007) 'Reflections on the lecture: Outmoded medium or instrument of inspiration?', Journal of Further and Higher Education, 31(4), pp. 397-406.

Kishimoto, K. and M. Mwangi. (2009) 'Critiquing the rhetoric of "safety" in feminist pedagogy: Women of color offering an account of ourselves', Feminist Teacher, 19(2), pp. 87-102.

Laliberté, N., Bain, A., Lankenau, G. and M. Bolduc (2017) 'The controversy capital of stealth feminism in higher education', Acme, 16(1), pp. 34-58.

Lang, J.M. (2016) Small Changes in Teaching. Available at:

https://www.chronicle.com/specialreport/Small-Changes-in-Teaching/44 (Accessed: 23 February 2018).

Mengel, F., Sauermann, J. and U. Zölitz. (2018) ‘Gender Bias in Teaching Evaluations’, Journal of the European Economic Association. doi: 10.1093/jeea/jvx057

Mrs Kinpaisby (2008), 'Taking stock of participatory geographies: Envisioning the communiversity', Transactions of the Institute of British Geographers, 33(3), pp. 292-299.

Padlet (2018) Padlet, Available at: https://padlet.com/ (Accessed: 23 February 2018).

Revell, A. and E. Wainwright (2009) 'What makes lectures "unmissable"? Insights into teaching excellence and active learning', Journal of Geography in Higher Education, 33(2), pp. 209-223.

Reza-Lopez, E., Charles L.H. and L. Reyes (2014) 'Nepantlera pedagaogy: An axiological posture for preparing critically conscious teachers in the borderlands', Journal of Latinos and Education, 13(2), pp. 107-119.

Roberts, M. (2011) What Makes a Geography Lesson Good?. Available at: https://www.geography.org.uk/download/ga_prmghwhatmakesageographylessongood.pdf (Accessed: 23 February 2018).

SIGJ2 Writing Collective (2012) 'What can we do? The challenge of being new academics in neoliberal universities', Antipode, 44, pp. 1055-1058. 
Tasch, J. and W. Tasch (2016) 'Redesigning Physical Geography 101: Bringing students into the discussion', Journal of Geography in Higher Education, 40(4), pp. 565-584.

Vygotsky, L. (1962) Thought and Language. Cambridge, MA: Massachusetts Institute of Technology Press. 